\title{
HYDRO-GEOMORPHIC FACTORS AND THE POTENTIAL OF HYDROKINETIC POWER PRODUCTION UPSTREAM OF IKERE GORGE DAM, NIGERIA
}

\author{
Wahab Salau ${ }^{1}$ and Ifatokun Ifabiyi Paul ${ }^{2}$ \\ ${ }^{1}$ Department of Geography, Faculty of Humanities, Management and Social Sciences, Federal \\ University of Kashere, PMB 0182, Gombe State, Nigeria \\ ${ }^{2}$ Department of Geography and Environmental Management, Faculty of Social Sciences, \\ University of Ilorin, PMB 1515, Ilorin, Nigeria \\ Email: salawiy@fukashere.edu.ng
}

Received 21 January 2019/ Revised 8 April 2019/ Accepted 11 April 2019/ Published Online 29 April 2019

\begin{abstract}
The operation of hydrokinetic turbine depends on river flow and pressure head $(\Delta \mathrm{H})$ which are of high potential in many parts of Nigeria. This study attempts the analysis of the potential of the area upstream of Ikere Gorge dam for hydrokinetic potential. Soil and Water Assessment Tool (SWAT) was used to determine the hydrological parameters of the sub-basins. Pearson Moment Correlation and linear regression methods were used to find the relationships between morphometric properties and the discharge parameters. Hydrological modeling and statistical computations were done to estimate the theoretical potential of the catchment. The result shows that River Oshe has 9.542 MW, which is the highest potential while River Konsun with 1.161 MW has the lowest potential Pearson Moment Correlation shows that there is strong positive relation of 0.7 between slope and pressure head $(\Delta \mathrm{H})$ at 0.05 significant levels. The result of the multiple regression show that hydro-geomorphic factors explained $59.1 \%$ of the variance in the explanation of hydrokinetic power potential upstream of Ikere gorge dam. The result shows that higher discharge is a function of more hydrokinetic energy that can be produced in the Basins. It is therefore expected that the variation in hydro geomorphic properties of the Basin will not affect substantial amount of hydrokinetic energy that can be produced from upstream of the basin under study. Hence, further work is expected to be replicated in some potential basins, across the country, for Hydrokinetic power production.
\end{abstract}

Keywords: Hydrokinetics, Hydraulic head, Gorge, Kinetic energy, Flow rate, Velocity

\section{Introduction}

Hydrokinetic energy is extracted from ocean currents, waves, rivers, canals, tide and from other sources. It require no impoundments, hence, externalities associated with dam construction and reservoir creation become irrelevant (Kosnik, 2008 in Bahleda \& Hosko, 2007). According to Ofuani (2013) the use of renewable energy as a means of addressing environmental 
Wahab Salau and Ifatokun Ifabiyi Paul/GEOSI Vol 4. No 1 (2019) 25-43

infractions is growing world-wide because of the environmental harms caused during the production and use of convectional/fossil resources. Greater demand for renewable energy has led to the considerable interest in the development and application of hydrokinetic contribution designed for river, tide and marine environment (Stephen, 2012).The Hydrokinetic energy's key difference to wind power is that water is over 800 times denser than air, making it a highly concentrated, reliable, and largely untapped resource. The renewable energy such as hydrokinetic is a step toward eradicating global energy crisis. It will go a long way to foster on diversification of power sector.

The pivotal role of renewable energy will also be a hub for sustainable energy development especially in developing countries of the world. Alternatively, hydrokinetic renewable energy does not need displace of settlement and people involved before it can be set up unlike hydropower project which may cause destruction of ecosystem and marine life. Flood and sediment are threat to dam which use to cause hydropower dam failure. The result of the failure is the displacement of people living at the downstream of a hydropower dams hence making hydrokinetic system to be safer. It has a big advantage over other clean energy technologies such as wind or solar, given that the start-up costs for small-scale hydrokinetic projects are much lower and power production begins much sooner. For most clean energy source, large plots of land are required, while many potential locations already in place are ready to produce hydrokinetic power (Evan, 2012). In hydropower system, the water wheels must be developed and perfected (Aschenbrenner, 2008).

Hydrokinetic energy is thought to be useful to decision makers regarding the potential benefits of using this technology in rural areas especially in countries with little or no elevation (Vermaak et al., 2013). In the study conducted by Kusakana, et al. (2013), they investigated the possibility of using and developing hydrokinetic power to supply reliable, affordable and sustainable electricity to rural, remote and isolated areas in rural South Africa where reasonable water resource is available. The advantages of hydrokinetics power over other powers include: the facts that is is simple and cheap to design and therefore suitable for rural electrification; it is an alternative means of ecotourism development; it is a medium of developing small scale industries and it is a means to curtailing rural-urban migration. Soil And Water Assessment Tool has been a veritable tool in drainage basin analysis, particularly in river basins where there is paucity of data like what obtain in the study area. Neitsch et al. (2009) reported that SWAT is a 
Wahab Salau and Ifatokun Ifabiyi Paul/GEOSI Vol 4. No 1 (2019) 25-43

catchment-scale continuous time model that operates on a daily time step with up to monthly/annual output frequency.

In a nutshell, the global concern over climate change will support the use of alternative energy sources such as hydrokinetic power to avert the effects of global warming. For example, reservoir construction contributes to earth climate change; hydroelectric dam construction is a major source of methane gas emission. This gas is one of GHGs causing global warming. Issue of power generation is a bane of rural development. Power availability will not only raise the standard of living but will enhance peoples livelihood (Wahab, Adeogun \& Ifabiyi (2017); Ifabiyi \& Wahab (2017). Its development in Nigeria would provide a platform for building a virile economy and usher-in massive rural and regional transformation. This research examined hydrokinetic potentials and its relationship with hydro-geomorphic factors in a rural community in western Nigeria.

Figure 1: Ikere Gorge Dam [Inset; Nigeria Map Showing Ikere Gorge Basin].




Wahab Salau and Ifatokun Ifabiyi Paul/GEOSI Vol 4. No 1 (2019) 25-43

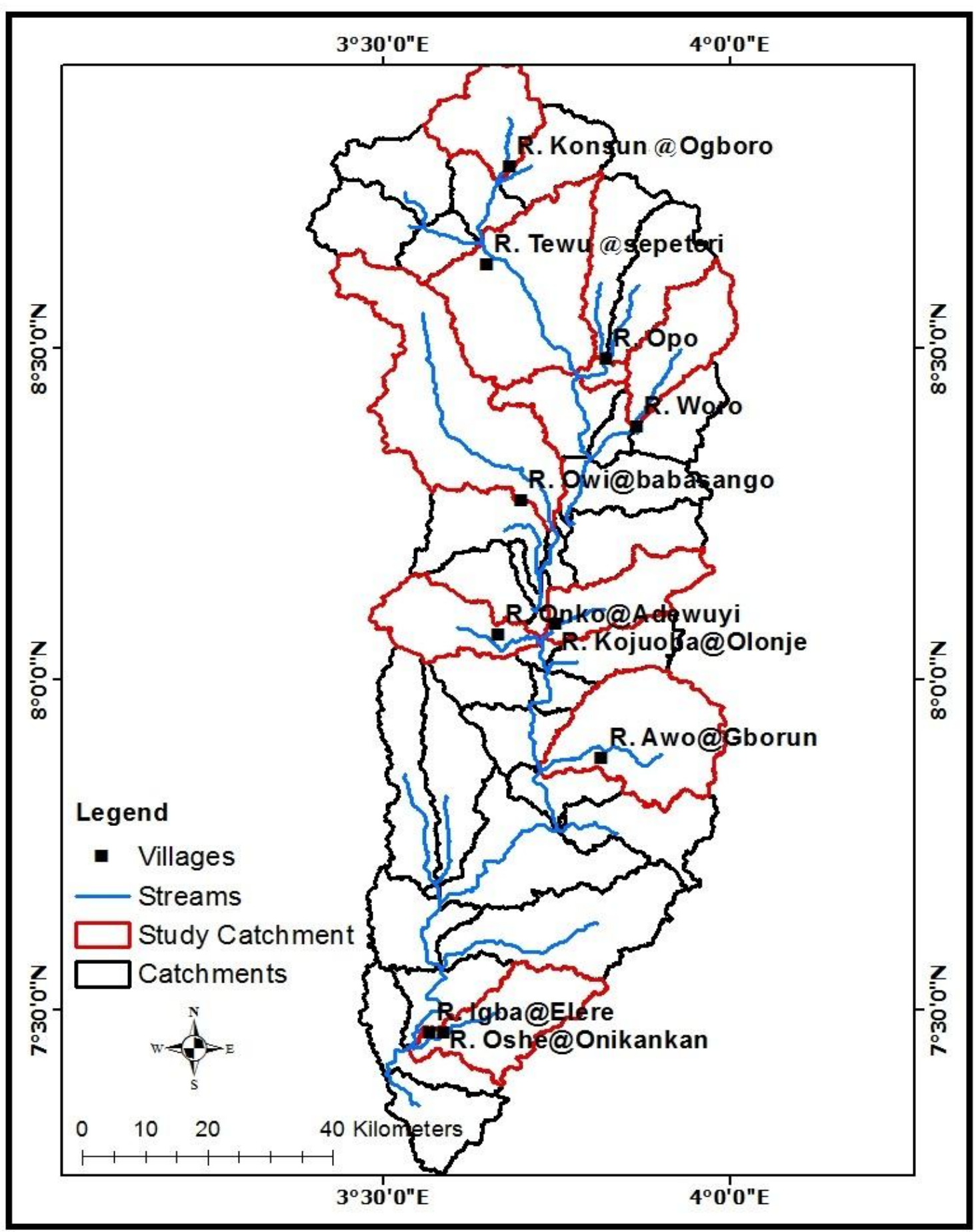

Figure 2: Drainage Network of the Upstream of Ikere Gorge Basin. 
Wahab Salau and Ifatokun Ifabiyi Paul/GEOSI Vol 4. No 1 (2019) 25-43

\section{The Methods}

The configuration of the model used includes setting of simulation start date and finish date with respect to selection of weather data from the SWAT database. The model was runned to execute the SWAT Model operation and the simulation period covered from January 01, 2004 to December 31, 2013. All the data gathered were input into the computer with the use of SWAT software to process the data in order to get the desirable results. The $90 \mathrm{~m}$ resolution extracted from Shuttle Radar Topographical Mission (SRTM) is used to acquire elevation of the selected locations within the watershed area. The Digital Elevation Model (DEM) enabled to delineate the watershed into sub-basins. With the use of SRTM data, terrain slope, straight length and channel slope were derived from Digital Elevation Model (DEM). MAPWINDOW and Hydrologic SWAT model was used to model location of some suitable sites in the river channels.

The model was used to determine the sub-basin having the highest potential for hydrokinetic power resource generation. Weather parameters such as minimum and maximum temperature, rainfall, relative humidity within the river basin for the period of 10 years were used for this analysis. The data acquired from Ogun Osun River Basin Development Authority and world global weather database of World Meteorological Agency was used for the analyses. Also, linear regression is used to find the relationship between the dependent or criterion variable and independent or predictor variables. The relationship between the morphometric properties and Hydrokinetic power potential is established through the linear regression equation:

$$
\mathrm{Y}=a+b 1 x 1+\ldots \ldots . . . b n x n+e .
$$

The dependent variable (Y) represents hydrokinetic energy potential while independent variables (x1 .....x2) represent morphometric properties. In order to estimate the energy potentials, the method used to derive energy potential includes standard hydrological engineering equation. The equation is used to relate theoretical hydraulic power (Pth, watts) to discharge $\left(\mathrm{Q}, \mathrm{m}^{3} / \mathrm{s}\right)$ and hydraulic head or change in elevation $\Delta \mathrm{H}(\mathrm{m})$ over the length of the segment. A multiplication of discharge values with the measured elevation and constant mass density gives the segment specific theoretical hydrokinetic power resource of the location. The theoretical hydraulic power potential can be calculated using the formula, 
Wahab Salau and Ifatokun Ifabiyi Paul/GEOSI Vol 4. No 1 (2019) 25-43

$$
\mathrm{P} t h=\gamma \mathrm{Q} \Delta \mathrm{H}
$$

Where:

Pth (watts) = theoretical hydraulic power,

$\gamma=$ Specific weight of water $\left(9800 \mathrm{n} / \mathrm{m}^{3}\right)$,

$\Delta \mathrm{H}(\mathrm{M})=$ Change in Hydraulic head between the beginning and end of the river segment or change in elevation over the length of the segment,

$\mathrm{Q}=$ Flow rate $\left(\mathrm{m}^{3} / \mathrm{s}\right)$.

This method was used by the Electric Power Research Institute (EPRI) in determining the theoretical riverine hydrokinetic resource for continental USA using assume river slope of $0.3 \mathrm{~m}$ (EPRI, 2012 in Ladokun et al., 2013). However, GIS system MAPWINDOW and Hydrologic SWAT model were used to model the location. Input files were configured and the model was runned automatically. Hence, the results were displayed through GIS interface MAPWINDOW. Also, the delineation of the watershed was carried out with the use of MAPWINDOW spatial tool. That is, Arc SWAT model were used to generate all the files needed through input from digitized map. Also, manual editing of the necessary data was carried out and the weather data of the basins were runned accordingly to get average daily discharge in order to calculate potential capacity of each river as it shown in Figure 3 and 4 respectively. 


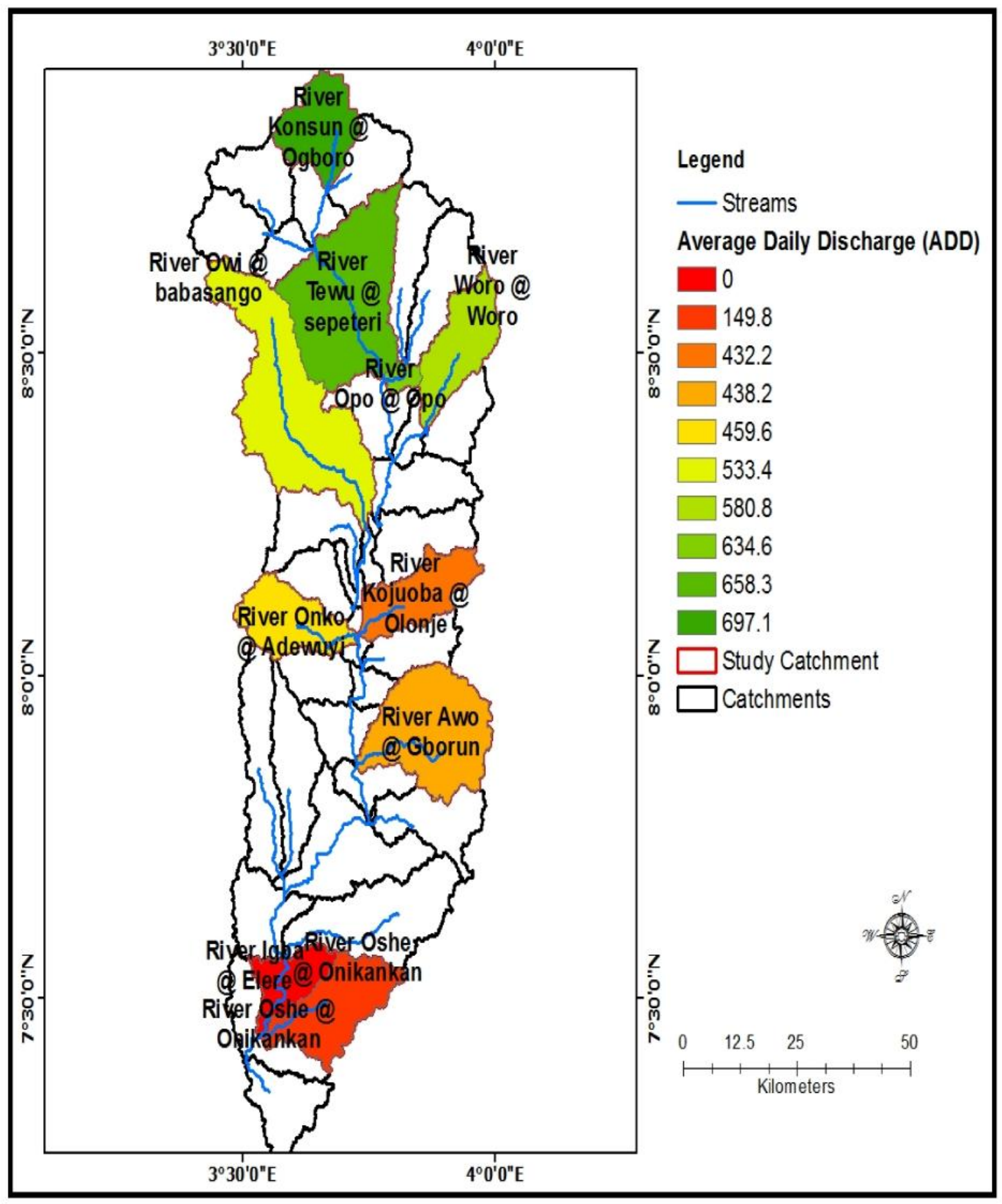

Figure 3: Average Daily Discharge of Rivers in Ikere Gorge Basin

Source: Author's computation. 


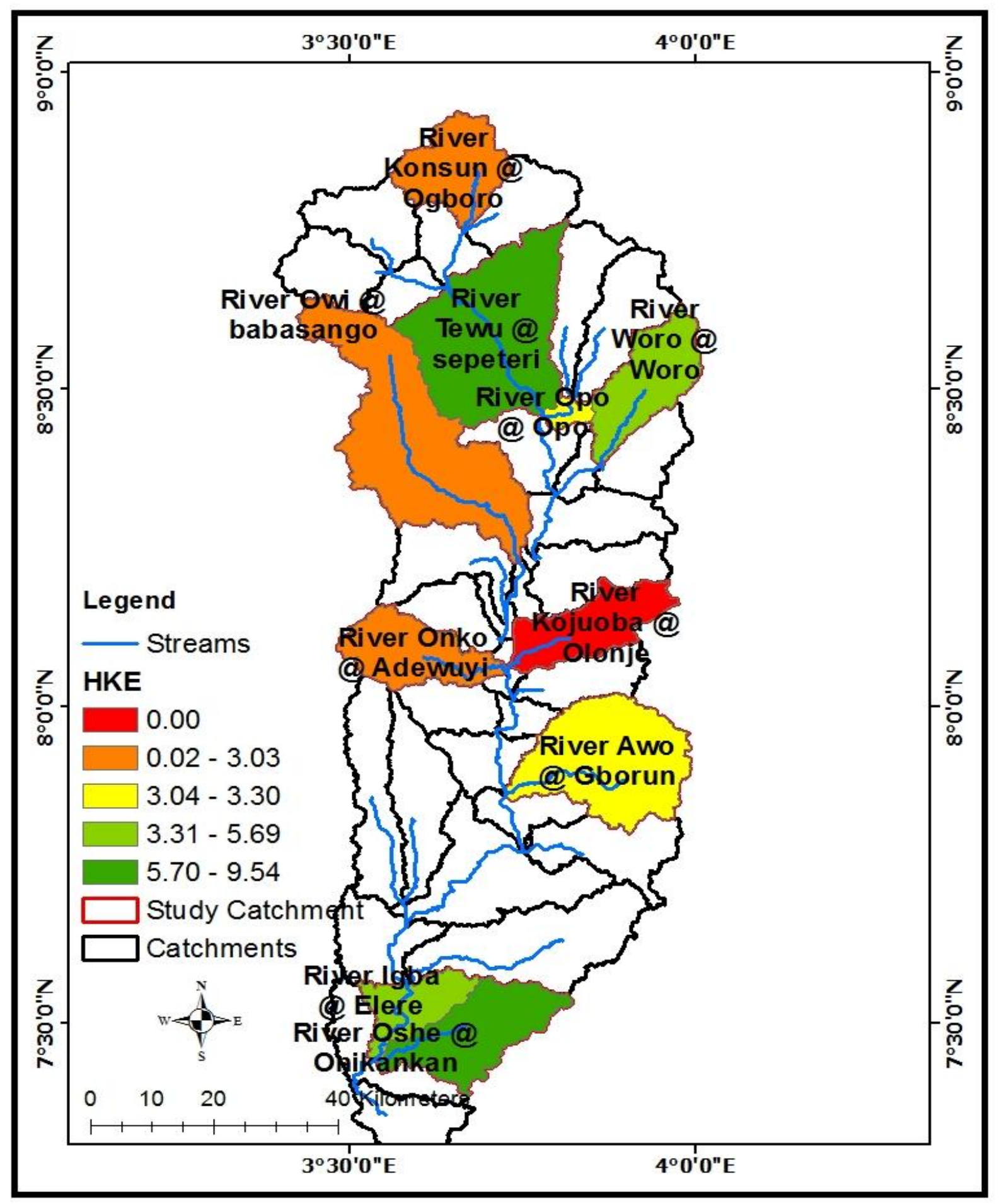

Figure 4: Hydrokinetic Potential Energy of Rivers in Ikere Gorge Basin Source: Author's computation. 
Wahab Salau and Ifatokun Ifabiyi Paul/GEOSI Vol 4. No 1 (2019) 25-43

\section{Result and Discussion}

\subsection{Hydrokinetic Potentials in the Upstream of Ikere Gorge Basin}

Data was sourced from Ogun River Basin Development Authority and World Meteorological database with the use of Soil-water Assessment Tool (SWAT) Software to estimate various parameters such as nature of the terrain, river order, river discharge, shape, etc. The result of the analysis shows that the strength of the average daily discharge of many rivers at the upstream of Ikere Gorge Basin is reasonably high to produce Hydrokinetic power. Also, correlation between morphometric properties and discharge parameters showed in Table 2 indicated that there is strong positive nexus between pressure head and channel slope. Hence, the values of theoretical hydrokinetic resource in Table 8 are functions of changes in water pressure head $(\Delta \mathrm{H})$, velocity and specific weight of water. It is therefore imperatives that there are some hidden factors responsible for the variation in the amount of hydrokinetic energy produced besides average daily discharge and morphometric properties. Also, Microsoft excels and Microsoft access software packages were used to generate the morphometric analysis of the basin under study.

Table 1: Basin Hydrologic Parameters of Ogun River Catchment

\begin{tabular}{lllllllll}
\hline $\begin{array}{c}\text { River } \\
\text { location }\end{array}$ & $\begin{array}{c}\text { Rivero } \\
\text { rder }\end{array}$ & $\begin{array}{c}\text { Head, } \\
\Delta \mathrm{h}(\mathrm{m})\end{array}$ & Slope $(\mathrm{m})$ & $\begin{array}{c}\text { Straight } \\
\text { Length } \\
(\mathrm{m})\end{array}$ & $\begin{array}{c}\text { Flow-in } \\
\left(\mathrm{m}^{3} / \mathrm{s}\right)\end{array}$ & $\begin{array}{c}\text { Flow-out } \\
\left(\mathrm{m}^{3} / \mathrm{s}\right)\end{array}$ & $\begin{array}{c}\text { Average } \\
\text { Daily } \\
\text { Discharge } \\
\left(\mathrm{m}^{3} / \mathrm{s}\right)\end{array}$ \\
\hline 1 & Konsun & 1 & 17.00 & 0.001299669591 & 11217.2 & 247885.0 & 260965.5 & 697.1 \\
2 & Tewu & 1 & 13.00 & 0.001978248862 & 5661.9 & 236996.8 & 243568.3 & 658.3 \\
3 & Opo & 1 & 53.00 & 0.002941717624 & 14828.9 & 222624.4 & 240641.4 & 634.6 \\
4 & Woro & 1 & 10.00 & 0.001408971636 & 6072.9 & 208438.6 & 215536.1 & 580.8 \\
5 & Onko & 1 & 62.00 & 0.0030009223338 & 15182.3 & 157408.5 & 178069.3 & 459.6 \\
6 & Awo & 1 & 76.00 & 0.001634228118 & 29663.0 & 136673.3 & 183179.3 & 438.2 \\
7 & Oshe & 1 & 65.00 & 0.002665049486 & 19324.8 & 42488.6 & 66878.0 & 149.8 \\
8 & Owi & 2 & 58.00 & 0.002107941192 & 20951.7 & 180923.1 & 208438.6 & 533.4 \\
9 & Kojuoba & 3 & 0.00 & 0.000000000000 & 612.8 & 157408.5 & 158070.1 & 432.2 \\
10 & Igba & 3 & 34.00 & 0.001480861115 & 14525.0 & 42488.6 & 65447.8 & 147.9 \\
\hline
\end{tabular}

Source: Author's computation.

The implication of the results of the SWAT shown in Table 1 depicted that there are 8 first order streams, 1 second order steam and 2 third order streams in the selected location. It was therefore imperatives that River Konsun which is one of the first orders River has the highest discharge of 
$697.1\left(\mathrm{~m}^{3} / \mathrm{s}\right)$ while River Igba has the lowest discharge of $147.9\left(\mathrm{~m}^{3} / \mathrm{s}\right)$. Also, River Awo recorded highest value for Head while River Kojuoba has the lowest Head. Not only have that, all the river had reasonable values of discharge that could be used to project hydrokinetic power production. The average daily discharges of each river were represented in Figure 5.

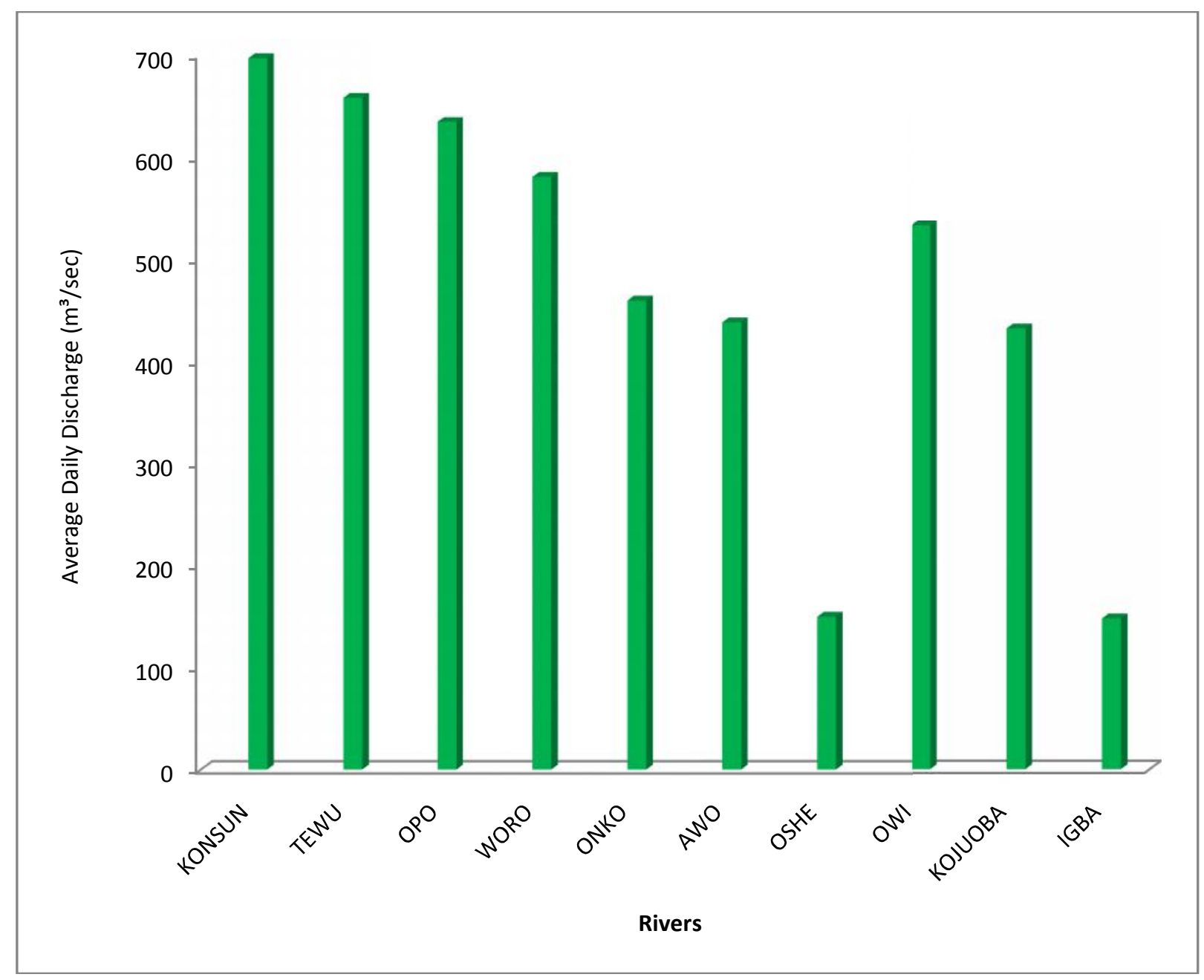

Figure 5: Pattern of Rivers and Average Daily Discharges

Source: Author's computation.

The result revealed the strength of the average daily discharge of some of the selected rivers in the river catchments is reasonably high to generate some power. The Alaska Center for Energy and Power (ACEP) (2011) reported that minimum velocity of water current that is required for hydrokinetic generation is between $1.03 \mathrm{~m} / \mathrm{s}$ and $2.06 \mathrm{~m} /$ and range of $2.57 \mathrm{~m} / \mathrm{s}$ and $3.6 \mathrm{~m} / \mathrm{s}$ for 
Wahab Salau and Ifatokun Ifabiyi Paul/GEOSI Vol 4. No 1 (2019) 25-43

optimum power generation. The results of average daily discharge presented in Table 1 point to the adequacy of flow in the (10) sub basins under consideration as discharge ranges from 147.9 $\mathrm{m}^{3} / \mathrm{s}$ in Igba to $697.1 \mathrm{~m}^{3} / \mathrm{s}$ in Konsun sub basin.

Table 2:Inter-correlation between Morphometric Properties and Discharge Parameters

\begin{tabular}{llllll}
\hline \multicolumn{1}{c}{ Variables } & $\Delta \mathrm{H}(\mathrm{m})$ & Slope $(\mathrm{m})$ & $\begin{array}{c}\text { Straight } \\
\text { length }(\mathrm{m})\end{array}$ & $\begin{array}{c}\text { Flow } \\
\mathrm{In}\left(\mathrm{m}^{3} / \mathrm{s}\right)\end{array}$ & Flow Out $\left(\mathrm{m}^{3} / \mathrm{s}\right)$ \\
\hline 1. Slope $(\mathrm{m})$ & $.700^{*}$ & & & & \\
2. Stream length (m) & $.924^{* *}$ & 0.486 & & & \\
3. Flow In $\left(\mathrm{m}^{3} / \mathrm{s}\right)$ & -.409 & -.053 & -.374 & & \\
4. Flow Out $\left(\mathrm{m}^{3} / \mathrm{s}\right)$ & -.267 & 0.016 & -.211 & $.985^{* *}$ & \\
$\begin{array}{l}\text { 5. Average daily discharge } \\
\left(\mathrm{m}^{3} / \mathrm{s}\right)\end{array}$ & -.341 & -.020 & -.296 & $.996^{* *}$ & $.996^{* *}$ \\
\hline
\end{tabular}

*. Correlation is significant at the 0.05 level (2-tailed).,

**. Correlation is significant at the 0.01 level (2-tailed).

Source: Author's Computation.

The result of the correlation analysis between morphometric properties and discharge parameters showed in Table 2 indicated that there is strong positive relationship existing between pressure head and channel slope at 0.05 significant levels. The pressure head and stream length have strong positive correlation suggesting that as pressure head increases, stream-length also increases. A strong positive correlation was also noticed between flow-in and flow-out along the basin, showing that as the volume of water entering channel increases, the output also increases. The result of Pearson moment correlation shows that there is strong positive relation between slope and this implies that as changes in pressure head increases, slope also increases. Hence, both are important factors in determining hydrokinetic power production. 
Wahab Salau and Ifatokun Ifabiyi Paul/GEOSI Vol 4. No 1 (2019) 25-43

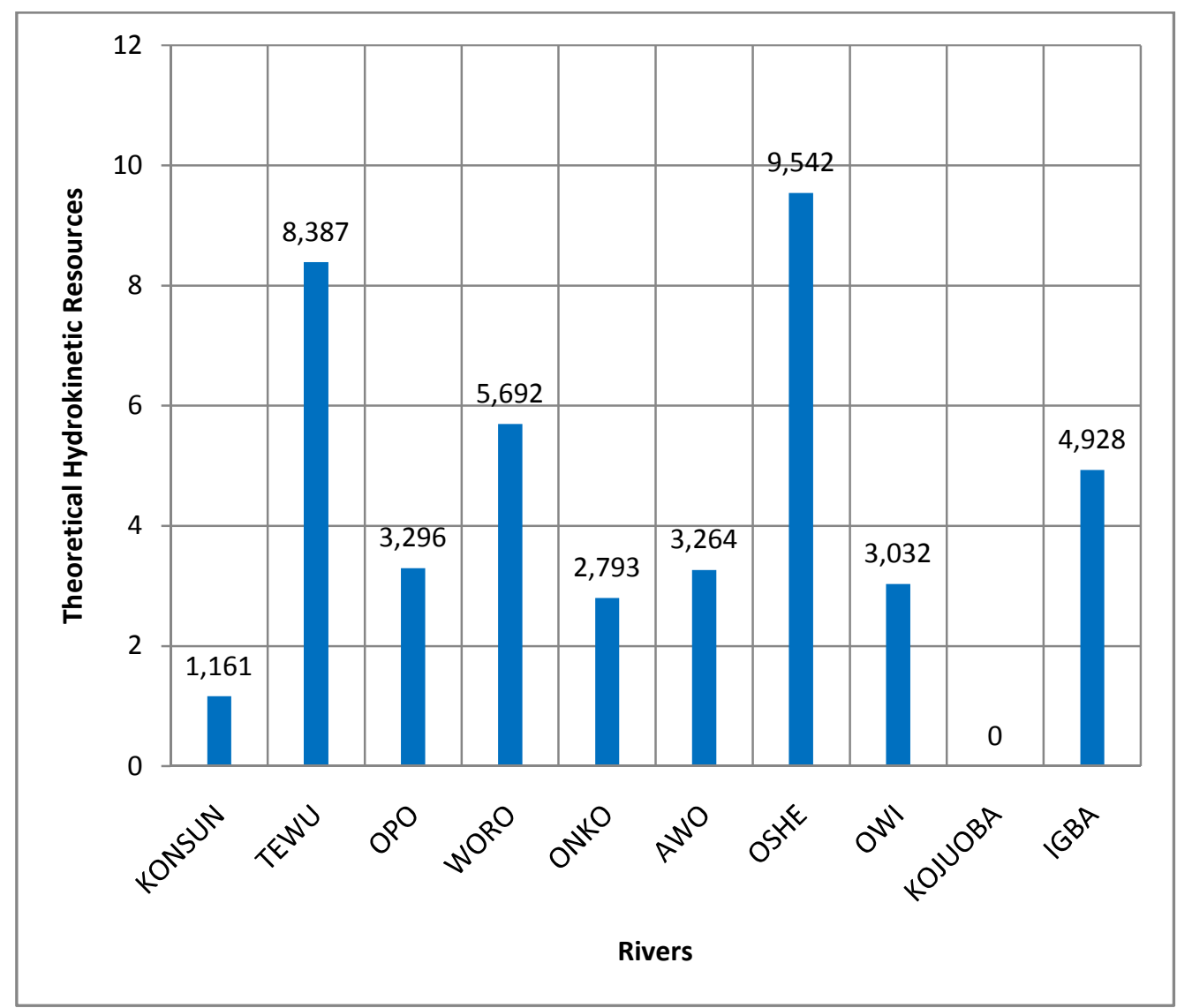

Figure 6: Pattern of Hydrokinetic Energy Potentials in the Ikere-Gorge Basins (x 106) Source: Author's computation.

3.3 Relationship between Potential Hydrokinetic Energy and Selected Hydro morphometric Variables

The result of the multiple regression analysis between Hydrokinetic energy and Hydro morphometric variables presented in Table 4 shows the model summary of combined parameters of flow-out, slope, straight length, $\Delta \mathrm{H}(\mathrm{m})$, flow- in and hydrokinetic energy potential with the adjusted $\mathrm{R}^{2}$ is $59.1 \%$.

Table 4: Regression Model Summary:

\begin{tabular}{llllll}
\hline Model & $\mathrm{R}$ & R Square & $\begin{array}{l}\text { Adjusted } \\
\text { Square }\end{array}$ & $\begin{array}{c}\text { R Std. Error of the } \\
\text { Estimate }\end{array}$ & \\
\hline 1 & $.769^{\mathrm{a}}$ & .591 & .080 & 2.87224 & \\
\hline
\end{tabular}

Predictors: (Constant), Flow Out ( $\left.\mathrm{m}^{3} / \mathrm{s}\right)$, Slope $(\mathrm{m})$, Straight length $(\mathrm{m}), \Delta \mathrm{H}(\mathrm{m})$, flow in $\left(\mathrm{m}^{3} / \mathrm{s}\right)$. Source: Author's computation.

From Table 4, it implies that multiple regression model for the combined variables with five explanatory variables have an $\mathrm{R}$ Square $\left(\mathrm{R}^{2}\right)$ value of 0.591 . This depicted that $59.1 \%$ variation 
Wahab Salau and Ifatokun Ifabiyi Paul/GEOSI Vol 4. No 1 (2019) 25-43

in hydrokinetic power production can be explained by this model in Table 4 implying that there are some hidden factors responsible for the variation apart from morphometric properties and average daily discharge.

Table 5: Relationship between morphometric properties and Average daily Discharge Coefficients

\begin{tabular}{|c|c|c|c|c|c|c|}
\hline \multirow{2}{*}{\multicolumn{2}{|c|}{ Model }} & \multicolumn{2}{|c|}{$\begin{array}{l}\text { Unstandardized } \\
\text { Coefficients }\end{array}$} & \multirow{2}{*}{$\begin{array}{l}\text { Standardized } \\
\text { Coefficients } \\
\text { Beta }\end{array}$} & \multirow[b]{2}{*}{$\mathrm{T}$} & \multirow[b]{2}{*}{ Sig. } \\
\hline & & $\bar{B}$ & Std. Error & & & \\
\hline 1 & (Constant) & 4.016 & 3.699 & & 1.086 & .339 \\
\hline & $\Delta \mathrm{H}(\mathrm{m})$ & $-.237-$ & .157 & $-2.152-$ & $-1.509-$ & .206 \\
\hline & Slope (m) & 44.337 & 22.983 & 1.340 & 1.929 & .126 \\
\hline & Stream length (m) & .000 & .001 & 1.158 & .425 & .693 \\
\hline & Flow In $\left(\mathrm{m}^{3} / \mathrm{s}\right)$ & $-3.199 \mathrm{E}-5$ & .001 & $-.783-$ & $-.057-$ & .957 \\
\hline & Flow Out $\left(\mathrm{m}^{3} / \mathrm{s}\right)$ & $3.970 \mathrm{E}-6$ & .001 & .091 & .007 & .995 \\
\hline
\end{tabular}

a. Dependent Variable: Hydrokinetic

Hydrokinetic Energy $(\mathrm{Y})=4.016-0.237$ Head +44.337 Slope +0.00 stream length -0.0003 flow in +0.0003 flow-out...... [3]

From Table 5, it implies that for every $1 \%$ decrease in $\Delta \mathrm{H}$ and flow-in, there is decrease in $-23.7 \%$ and $-31.99 \%$ decrease in hydrokinetic power production. On the other hand, for every 1 $\%$ increase in slope, flow-out, there is $44.33 \%$ and $39.7 \%$ in hydrokinetic power production as it shown in equation 3.

Therefore, the relationship between the morphometric variables and hydrokinetic power is given in the linear equation as follows:

$$
\mathrm{Y}=\mathrm{a}+\mathrm{bx}
$$

The Estimated model equation is given by this equation as follow:

Hydrokinetic Energy $=4.016-0.237_{\Delta H}+44.337_{\text {Slope }}+0.00$ Straight length -0.00003 flow in +0.0003 flow [5]

On the other hand, the trend equation model can be used to predict the selected variables and the hydrokinetic power potential as shown in the equation $\mathrm{Y}=\mathrm{a}+\mathrm{b} \mathrm{x}$ and the result is represented in the Table 6. 
Wahab Salau and Ifatokun Ifabiyi Paul/GEOSI Vol 4. No 1 (2019) 25-43

Table 6: Trend Equation Model of the Studied Variables

\begin{tabular}{lll}
\hline & Variables & Trends Equation Model \\
\hline 1. & Head, $\Delta \mathrm{H}(\mathrm{m})$ & $\mathrm{Y}=3.559+0.17 \mathrm{X}$ \\
2. & Slope $(\mathrm{m})$ & $\mathrm{Y}=1.511+14.569 \mathrm{X}$ \\
3. & Straight Length $(\mathrm{m})$ & $\mathrm{Y}=3.746+3.357 \mathrm{X}$ \\
4. & Flow in $\left(\mathrm{m}^{3} / \mathrm{s}\right)$ & $\mathrm{Y}=6.337-1.303 \mathrm{X}$ \\
5. & Flow out $\left(\mathrm{m}^{3} / \mathrm{s}\right)$ & $\mathrm{Y}=6.814-1.430 \mathrm{X}$ \\
\hline
\end{tabular}

Source: Author's computation.

The trend equation models in Table 6 can be used to predict the selected variables and the hydrokinetic power potentials of Ogun river basin at the upper catchment of Ikere gorge basin.

Table 7: Linear Regression Analysis between Morphometric Properties and Hydrokinetic Power Potential

\begin{tabular}{|c|c|c|c|c|c|}
\hline Variables & & $\mathrm{R}^{2}$ & Std. Error & Significant & Linear Equation \\
\hline 1. Head, $\Delta \mathrm{H}(\mathrm{m})$ & & 2.30 & 3.13694 & .674 & $Y=3.559+0.17 X$ \\
\hline 2. Slope $(\mathrm{m})$ & & 19.4 & 2.85242 & .203 & $Y=1.511+14.569 X$ \\
\hline $\begin{array}{l}\text { 3.Stream } \\
(\mathrm{m})\end{array}$ & Length & 0.9 & 3.16249 & .795 & $Y=3.746+3.357 X$ \\
\hline 4. Flow in $\left(\mathrm{m}^{3} / \mathrm{s}\right)$ & & 10.2 & 3.01082 & .3694 & $Y=6.337-1.303 X$ \\
\hline 5. Flow out $\left(\mathrm{m}^{3} / \mathrm{s}\right)$ & & 10.8 & 2.99995 & .353 & $Y=6.814-1.430 X$ \\
\hline
\end{tabular}

Source: Author's computation.

The linear regression equation can be expressed as $\mathrm{Y}=\mathrm{a}+\mathrm{b} \mathrm{x}$

Where,

$\mathrm{Y}=$ Hydrokinetic power potentials of the basin, $\mathrm{a}=$ intercept, $\mathrm{b}=$ slope, $\mathrm{c}=$ constant

Table 7 displayed the result of the linear regression analysis which implies that pressure head explain $2.3 \%$ variability on hydrokinetic power potential. The reason may be that there are still other strong factors that are influencing the output of hydrokinetic power production of Ogun River basins. The percentage of $\mathrm{R}^{2}$ varies from $0.9 \%$ to $19.4 \%$. Also, the results of the simple linear regression analysis shows that slope explained $19.4 \%$ variability of hydrokinetic power potential. Slope is a strong factor influencing power potential although there are other factors influencing the output of hydrokinetic power production in Ikere Gorge basins. Miller et al. (2010) reported that Hydro Kinetic Power [HKP] has a lower cost per unit of energy extracted than Hydro Potential Power [HPP] system, and is economically compared with other distributed system such as solar, wind and others making it a better method for policy support and compliance. Therefore, government and non-governmental organization should invest on hydrokinetic energy for human and socio-economic building of the country including industrial growth and development. 
Wahab Salau and Ifatokun Ifabiyi Paul/GEOSI Vol 4. No 1 (2019) 25-43

\section{Conclusion}

The trends in the evolution of science and technology call for friendly alternative source of energy production. Climate change and changing system in world order call for reliable energy that will sustain man's environment now and in the future.Therefore, there is the need to focus more on the benefits of hydrokinetic and what it can do to promote economy in this age of technological advancement. This technology of hydrokinetic will be useful in augmenting energy crisis especially at local level which serves as the backbone of the economy of this nation. The chosen sites are suitable to promote hydrokinetic energy technology; it is one of many potential sites in Nigeria to boost electricity production.

\section{References}

Alaska Center for Energy and Power (ACEP) (2011). Hydrokinetic energy (In-River, Tidal and Ocean Current), Retrieved from http://energy-alaska.wikidot.com/ on April 20 ${ }^{\text {th }}, 2014$ Aschenbrenner, F. (2008). Innovation on traditional waterwheels for renewable energy // Power electronics and motion Control conference, Portoroz, Slovenia, pp.1625

Bahleda, M., and Hosko, M. A. (2007). Assessment of water power potential and development Needs: Electric power research institute, California

Bhattacharya, A.K., and Bolaji, G.A. (2012). Fluid Flow Interactions in Ogun River, International Journal of Research and Reviews in Applied Sciences, 2 (2): 22-23.

Electric Power Research Institute, EPRI (2012). Fish passage through turbine: Application of convectional hydropower data to hydrokinetic technology Palo Alto, USA

Energy Information Administration (2014). Retrieved on Dec. 20th, 2014 from www.eia.gov/electricity

Epler, J. (2010). Tidal Resources characteristics from acoustics Doppler current profiler, An Unpublished M.Sc.Thesis, Department of Mechanical Engineering, University of Washington, USA

Evan, M. (2012). Hydrokinetic Power: An Analysis of Its Performance and Potential in the Roza and Kittas Canals. An Unpublished M. Sc. Thesis, the Evergreen State College, USA

Ifabiyi, I.P. and Wahab, S. (2017). Theoretical potential of hydrokinetic energy in the Upper 
Wahab Salau and Ifatokun Ifabiyi Paul/GEOSI Vol 4. No 1 (2019) 25-43

Ogun and Upper Kaduna River basins, Nigeria. Journal of Sustainable Development in Africa, 19 (1): 242-256. Clarion University of Pennsylvania, Clarion, USA. ISSN: 15205509.Jsd-africa@clarion.edu

Kosnik, L. (2008). The Potential of Water Power in the Fight against Global Warming in the USA, Energy policy, doi: 10.1016/ J. enpol. (05), 009.

Kusakana, K., and Vermaak, H. J. (2013). Hydrokinetic Power Generation for Rural Electricity Supply: Case of South Africa. Renewable Energy, 1 (55): 467-73.

Ladokun, L.L., Ajao, K.R., and Sule, B.F. (2013). Hydrokinetic Energy Conversion System: Pros -pects and Challenges in Nigerian Hydrological setting, Nigerian Journal of Technology, 3 (32): 538-549.

Miller, V.B, Ramde, E.W., Grandoville, R.T., and Schaefer, L.A. (2010). Hydrokinetic Power for Energy Access in Rural Ghana, Renewable Energy International Journal, 1(36): 671675.

Mohibullah, M., Radzi, A. M., and Hakim, M.I.A. (2004). Basics Design Aspects of Micro Hydropower Plant and Its Potential Development in Malaysia // Power and Energy Conference, Kualar Lumpur, pp. 220-223.

Neitsch, S.L, Arnold, J.G., Kiniry, J.R and Williams, J.R. (2009). Soil and Water Assessment Tool Theoretical Documentation Version 2009 Grassland, Soil and Water Research Laboratory-Agriculture Research Service, Blackland Research Center-Texas Agrilife Research., USA.

Ofuani, A.I. (2013). Combating climate change through renewable energy legislation in Nigeria: Prospects and Challenges. Paper Presented at university of Ilorin/ UCC (Ghana) International Conference held at university of Ilorin. May $1^{\text {st }}-4^{\text {th }} 2011$.

Stephen, V.A, Paul, T.A., and Daniel, J.G. (2012). Survival and Behaviour of Fish interacting With Hydrokinetic Turbines, $9^{\text {th }}$ ISE, Vienna, USA

Vermaak, H.J., Kusakana, K., and Koko, S.P. (2013). Status of Micro-hydrokinetic River Technology in Rural Applications: A Review of literature: Renewable and sustainable energy reviews, 29(14): 625-633.

Wahab, S., Ifabiyi, I.P. and Adeogun, A.G. (20017). SWAT analysis of Ikere Gorge Basin for 
Wahab Salau and Ifatokun Ifabiyi Paul/GEOSI Vol 4. No 1 (2019) 25-43

Hydrokinetic power estimation in selected rural settlement of Oke Ogun, Nigeria. Ruhuna Journal of Science. 8(2):24-43 Ruhuna, Faculty of Science, University of Ruhuna, Sri Lanka. eISSN: 2536-8400. DOI: http//:doi.org/10.4038/rjs.v8il. 